\title{
DECISION MAKING FRAMEWORK FOR DECREASING THE REDUNDANCY OF AIR QUALITY MONITORING STATIONS IN VOJVODINA PROVINCE (SERBIA)
}

\author{
Bogdana Vujic, Zorica Srdjevic, Boris Agarski, Katica Simunovic
}

Original scientific paper

Air quality monitoring stations are used for quick and reliable assessment of air quality. Although the stations are expensive, very often their number on certain territory exceeds optimal number of stations leading to their redundancy, increased costs, overlapping of data etc. To enable analysis of quantitative and qualitative criteria, authors propose an approach based on well-known decision support tool called analytic hierarchy process (AHP). As the first step in defining the decision framework for decreasing redundancy of stations locally and regionally in Vojvodina Province, three experts were asked to identify key performance indicators for assessing the performance of the stations. Fifteen indicators were selected and divided into three groups (Environmental objectives; Location/Technical objectives; and Social/Economic objectives). Experts evaluated performance of two stations in Municipality of Kikinda. Station KIMA showed better overall performance, so it is suggested to responsible authorities to relocate monitors from KISA station to KIMA station and thus decrease maintenance and operation costs.

Keywords: air quality monitoring station; analytic hierarchy process; multi-criteria; redundancy

Okvir za donošenje odluka o smanjenju suvišnih stanica za praćenje kvalitete zraka u pokrajini Vojvodina (Srbija)

Izvorni znanstveni članak Stanice za praćenje kvalitete zraka se koriste za brzo i pouzdano vrednovanje kvalitete zraka. Bez obzira što su stanice skupe, vrlo često njihov broj na određenom teritoriju prelazi optimalni broj stanica što rezultira njihovim viškom, povećanim troškovima, preklapanjem podataka itd. Da bi omogućili analizu kvantitativnih i kvalitativnih kriterija, autori predlažu pristup temeljen na dobro poznatom alatu za donošenje odluka pod nazivom Analitički hijerarhijski proces (AHP). U prvom koraku definiranja okvira za donošenje odluka o smanjenju suvišnih stanica na lokalnoj i regionalnoj razini u pokrajini Vojvodini, tri eksperta su identificirala ključne indikatore za ocjenjivanje karakteristika stanica. Petnaest indikatora je izabrano i podijeljeno u trì grupe (ciljevi životne sredine, ciljevi lokacije/tehnički; socijalno/ekonomski ciljevi). Prema predloženoj metodologiji eksperti su vrednovali dvije stanice u općini Kikinda. Stanica KIMA je imala bolje ukupne karakteristike, zbog čega je odgovornima predloženo da premjeste mjernu opremu iz KISA stanice u KIMA stanicu te tako smanje troškove održavanja i operacijske troškove.

Ključne riječi: analitički hijerarhijski proces; stanica za praćenje kvalitete zraka; višak; višekriterijski

\section{Introduction}

Nowadays the information on air quality is of great significance, especially in a highly polluted area where air quality assessment is a basis for decision makers to define measures for reducing the pollution and ensuring the public health protection. Different types of pollution sources, but dominantly anthropogenic activities (industry and traffic) in combination with environment conditions (meteorology and terrain), can cause high pollution levels in just a couple hours. Reliable detection of short or long term changes and assessment of air quality are enabled by establishing local, national or regional monitoring networks (AQMN - Air Quality Monitoring Networks).

The control of ambient air quality in Serbia, from its beginning in 1991 until now, went through different phases which included different scopes and levels of control. Beginning of the air quality measurement is related to the first law on environment issues which was adopted in 1991 [1]. Measurements were carried out by passive sampling within the network of basic meteorological and urban stations. During the 2000s a shift from a passive to an automatic monitoring sporadically occurred. This most important step towards improvement of ambient air protection system was, however, not systematically planned. As a consequence, on the territory of Vojvodina Province, Serbia, AQMN was set and implemented on several administrative levels. Local network within the jurisdiction of the City of Pancevo (CP), which contains four air quality monitoring stations (AQMS) in urban and suburban area, was first established in 2005. Regional network of seven stations within the jurisdiction of the Provincial Secretariat for Construction and Environmental Protection (PSCEP) was established in 2007. Finally, in 2008, a national network within the jurisdiction of the Serbian Environmental Protection Agency (SEPA) was established setting six AQMS on Vojvodina territory. At the moment, there are 17 active AQMS in Vojvodina (Fig. 1).

Although the United States Environmental Protection Agency recommends the assessment of the AQMN every five years [2], the assessment of AQMN in Vojvodina has not yet been performed. Besides that, the maintenance and operation of AQMS are expensive and reduction of those costs becomes very important in the transitional Serbian economy. Accordingly, authorities responsible for air quality management (CP, PSCEP and SEPA) that bear most of the costs, are interested to revise the necessity of certain AQMS to remain part of the network.

There are different approaches to AQMN revision. They include "site-by-site" method which is suitable for identification of monitors which could be relocated [3], "bottom-up" method which analyses phenomena that lead to increased concentrations of pollutants [4] and network optimisation using different analysis techniques including statistical methods, principal component analysis and cluster analysis, for identification of redundant measuring points $[5,6]$. Many authors also use different methods of multi-criteria analysis: combined with other methods $[7 \div 14]$ or independently $[15,16,17]$.

In this paper, authors propose evaluation of AQMS performance using the Analytic Hierarchy Process (AHP) 
[18], a well-known multi-criteria method. Many applications of AHP in the air pollution problems include AHP as part of the solving methodology [7, 9, 19, 20, 21]. Authors believe that AHP should be used for the whole AQMS evaluation procedure, because it (1) enables better insight of the decision makers into the problem by decomposing the complex one into the smaller, easier to comprehend, problems; (2) enables analysis of cardinal values of importance criteria and their influence on final decision; (3) includes both qualitative and quantitative decision criteria in the analysis; (4) provides both weights of the decision alternatives and ranks; and (5) supports group decision making.

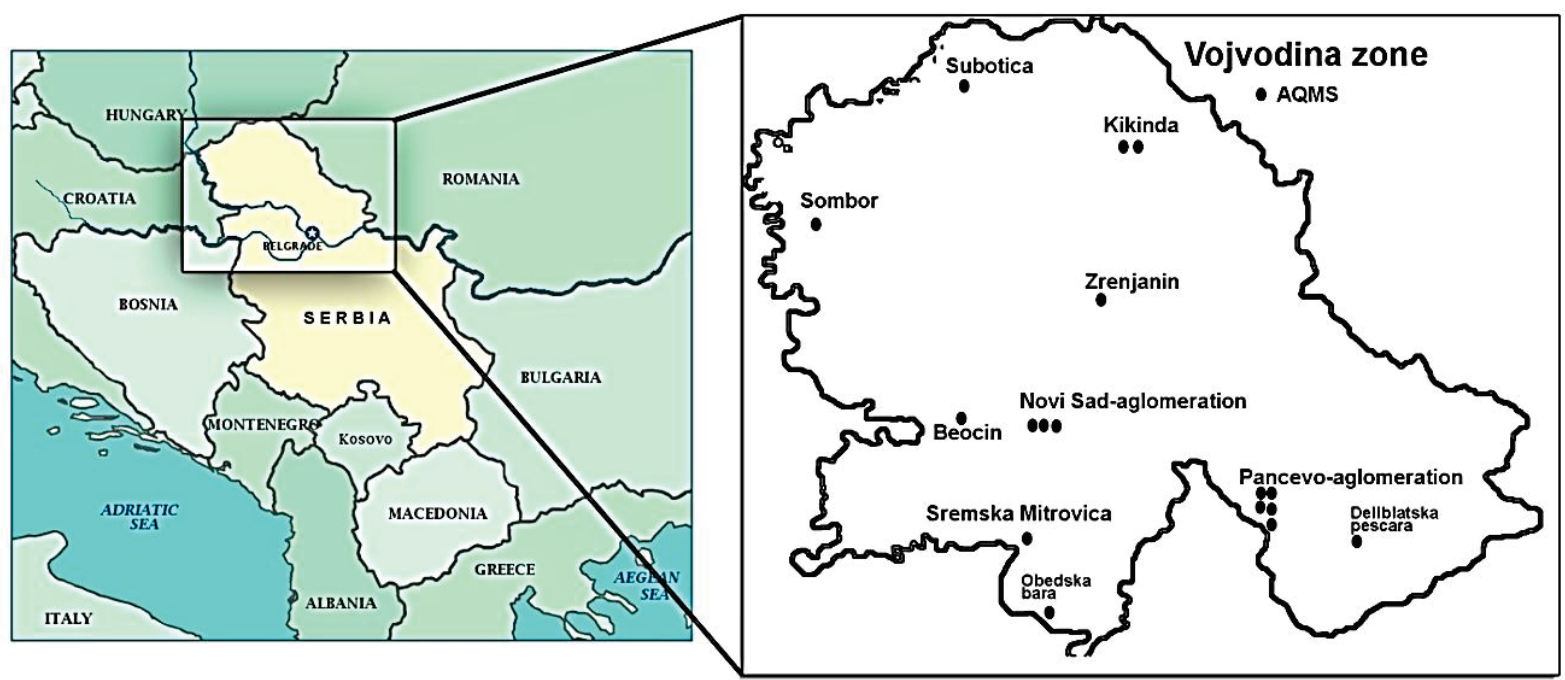

Figure 1 Location of AQMSs in Vojvodina Province

AHP based decision making framework is set here by first identifying key performance indicators for the assessment of AQMS at local and regional level in Vojvodina Province, and second by defining their importance for performance assessment. Three experts were asked to participate in building the framework. Experts identified 15 indicators that were grouped according to three objectives (Environmental, Location/Technical and Social/Economic) in order to gain a better insight into the importance of each of the objectives for AQMS evaluation, as well as the importance of indicators within the groups. After brief introduction to AHP, objectives and indicators were evaluated by experts in pair-wise manner according to AHP methodology and using the linguistic scale. Consensual judgments reached through discussion of experts were then converted into numbers and used to calculate relative importance (also called local weight) of objectives and indicators through the standard AHP approach.

Established decision framework is used to identify the more suitable of existing two AQMS (KISA, and KIMA) in the Municipality of Kikinda, in order to decrease costs of maintenance and operation borne by the responsible authority. Two stations are located very near, and the authority has expressed the interest to keep one station (selected as more suitable by experts) and relocate the monitors from the less preferred station to the selected one. Both stations were evaluated regarding given indicators, again as a consensus of experts on linguistic judgments reached through discussion. Converting those judgments to numbers and calculating local weights of stations enabled AHP synthesis and identification of better performing station.

\section{Methodology \\ 2.1 AHP in brief}

Analytic hierarchy process is a popular, widely used, decision support method, covered by extensive literature on both theory and practice. Basics of the method can be found in seminal book of Saaty [18], so it will be just briefly explained here.

AHP requires hierarchical structure formed by decomposing the complex problem into the hierarchy of interrelated elements (goal, criteria, sub-criteria and decision alternatives at the bottom of the hierarchy). Elements in one level are compared in pairs with regard to the elements in the upper level, using the Saaty's importance scale $\{1 / 9,1 / 8,1 / 7,1 / 6,1 / 5,1 / 4,1 / 3,1 / 2,1$, $2,3,4,5,6,7,8,9\}$. After all comparisons are made for the elements in one level, one can calculate relative priorities or local weights of the given elements. Procedure is repeated for all hierarchy levels and all elements.

Relative importance of all elements of the hierarchy is then synthesized by multiplying the criteria-specific priority vector of the alternatives with the corresponding criterion weight and summing up the results to obtain the final composite alternatives' priorities (weights) with respect to the goal and their ranking. First ranked alternative is considered as the best in the multi-criteria sense.

Important part of AHP is the calculation of consistency ratio. Consistency ratio presents the decision maker consistency measure of pair-wise comparisons and subjective judgements. If the value of consistency ratio is below 0,1 , the decision maker judgements are considered as consistent. 


\subsection{Decision framework for evaluating AQMS performance}

First step in establishing the decision framework for AQMS performance evaluation on local and regional level in Vojvodina province was to identify key performance indicators. This step is followed by evaluation of indicators in AHP manner to assess their importance for the AQMS performance evaluation. Three experts with significant experience in the field of the air quality monitoring are asked to participate in indicators selection and evaluation.

\subsubsection{Step 1: Key $A Q M S$ performance indicators identification}

Fifteen indicators were selected by the experts and later grouped according to the following objectives:

\section{Environmental objective.}

The concentration levels (ConcLevels). The individual monitors were ranked based on several criteria: pollutant concentrations levels, number of exceedance of limit values and margin of tolerance as well as the upper and lower assessment thresholds. Monitors that measure high concentrations are highly ranked because of its importance for achieving the regulatory objectives [22].

Total emission (TotEmiss). Type and capacity of pollution sources is crucial for determining the ambient air quality. Based on data from the National register of pollution sources [23], the stations were classified according to the total emissions. The station that is exposed to a greater amount of emissions is more significant.

Data Coverage (DataCover). Data coverage is very important for air quality assessment. The requirements in terms of available data for statistical calculations are defined by the Regulation on conditions for monitoring and requirements of air quality [22]. Stations that are in compliance with the proposed data coverage are more valuable.

Trend impact (TrendImp). This analysis includes the magnitude and direction of concentrations trend. Monitors that show a declining trend of concentration with no significant fluctuations can be considered as less important [24].

"Monitor to monitor" correlation (MonitToMonit). Concentration levels of a pollutant at different locations can be compared in order to determine their correlation. Analysis can be carried out by using regression analysis, and Pearson correlation coefficient. This criterion can be used as a basis for reduction of certain types of monitors [24].

Deviation of limit value (DevLimit). The absolute value of the difference of measured and limit values is being used. Monitors with the smallest absolute difference are treated as more significant [25].

2. Location/technical objective.

Location representatives (LocatRepres). Location representativeness and compliance with the requirements defined by national legislation [22] and the EU directive $[26,27]$ imply fulfilling a series of requirements that primarily depend on station type. Within this criterion, a series of sub-criteria concerning sitting issues which can affect the representativeness of samples (the distance from point and diffuse sources, position of the sampling probe tube, free air flow, direct emissions impact, direction of dominant winds, expected pollutants from near emission sources) have to be taken into consideration as well. A station that does not meet this criterion is considered as less important [28].

Area served (AreaServ). Determination of area representativeness is of particular importance when determining exposure (populations, ecosystems or materials). It is a complex process that involves extensive monitoring at several adjacent locations which cover the area around the AQMS or detailed dispersion model which is based on pollution register data for the study area [3]. Stations will be evaluated according to the area representativeness for a given station type [29].

Station accessibility (StatAccessib). This performance indicator includes the following analysis:

a) Location safety - indicates that the station is located in a safe environment.

b) Location Accessibility indicates the possibility of unhindered access to the station during regular service or checking.

c) The availability of electricity and telephone linesSome areas, especially in the case of rural background stations, may have limited access to necessary infrastructure. The station which requires special conditions (aggregates, power supply from large distances, mobile telephony) ranks as less significant.

d) Technical staff security [22].

Number of monitors and measurement methods (NumParam). AQMS that contain more than one monitor are much more valuable for specific pollution sources monitoring, as well as from the economic aspects (it is cost-effective to maintain station with more than one monitor) $[3,30]$. It is also valuable if the measurement methods are in accordance with the reference methods. Measuring stations that have fulfilled the listed requirements should be considered as more important.

Historical data (HistData). Monitors with data of several years are important for monitoring the concentration trends. Monitors that have data for a number of years are evaluated as more important [3].

\section{Social/Economic objective.}

Potentially Exposed Population (ExposedPopul). Stations were evaluated according to the total number of inhabitants (population) in the territory of the municipality as well as on population density. Stations which serve a larger population and areas with higher population density are more preferable.

Information availability (InfAvailab). The presentation and information availability of the air quality data is evaluated. Stations that have air quality index, online data, annual reports are evaluated as more important.

Operational cost (OperCost) and maintenance cost (MaintenCost). Lack of financial support for the efficient work is highly reflected on the environmental objectives, primarily on data coverage. On the other hand, if a station has multiple monitors or the station is located in areas (rural and natural) which require extra costs for the infrastructure provision (electricity and communication), operational costs will be higher. 


\subsubsection{Step 2: Defining the importance of objectives and indicators}

First step in AHP application in calculating priorities of objectives and indicators is to build the hierarchy of the problem. For this study, based on the indicators identified by the experts, AHP model for evaluation of AQMS performance at local and regional level in Vojvodina Province is formulated and presented in Fig. 2. Model includes 3 criteria (objectives) and 15 sub-criteria (indicators) that will be used to identify most suitable AQMS according to the performance of the stations.

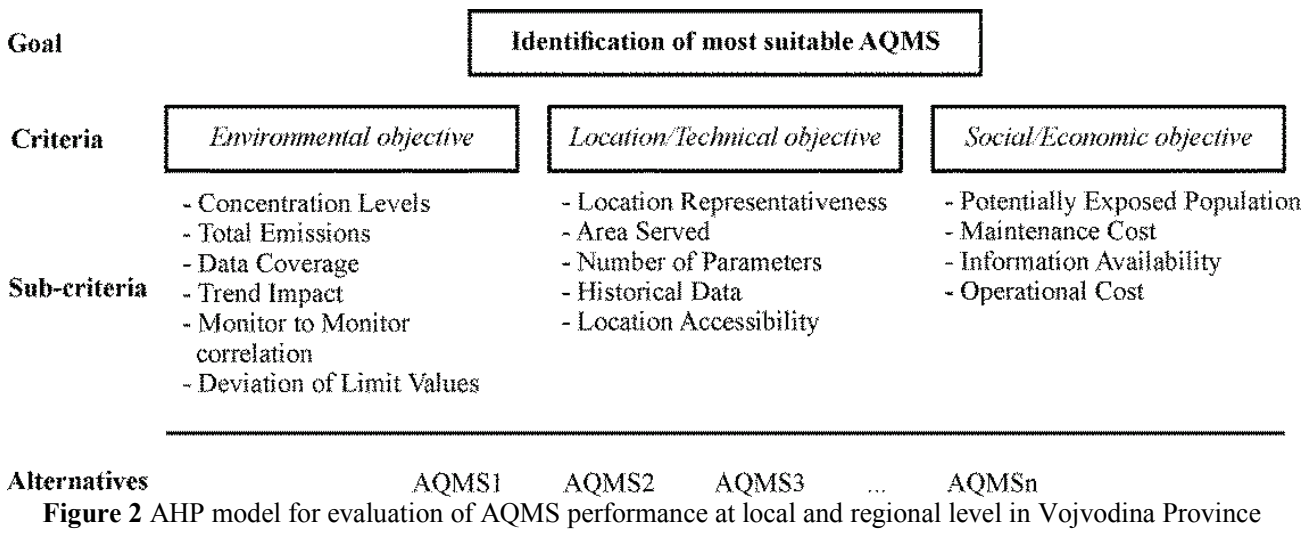

After defining the AHP model, a new session is organized in order to achieve agreement of experts on importance of objectives in reaching the goal, and importance of indicators regarding related objective. Experts were asked to compare in pairs objectives and indicators and find, using the linguistic Saaty's scale, consensual linguistic judgments through discussion. Linguistic judgments were later converted to numerical judgments, and the following local weights of objectives and related indicators were calculated (Tab. 1). Calculated consistency ratio was below 0,02 for all the AHP judgments, and this confirms that the experts were consistent in their decisions.

Table 1 Weights of objectives and indicators

\begin{tabular}{|c|c|c|c|}
\hline Objectives & Weights & Indicators & Weights \\
\hline \multirow{6}{*}{ Environmental } & \multirow{6}{*}{0,570} & ConcLevels & 0,476 \\
\hline & & TotEmiss & 0,219 \\
\hline & & DataCover & 0,076 \\
\hline & & TrendImp & 0,065 \\
\hline & & MonitToMonit & 0,105 \\
\hline & & DevLimit & 0,059 \\
\hline \multirow{5}{*}{ Location/Technical } & \multirow{5}{*}{0,333} & LocatRepres & 0,578 \\
\hline & & AreaServ & 0,181 \\
\hline & & NumParam & 0,096 \\
\hline & & HistData & 0,054 \\
\hline & & StatAccessib & 0,091 \\
\hline \multirow{4}{*}{ Social/Economic } & \multirow{4}{*}{0,097} & ExposedPopul & 0,375 \\
\hline & & MaintenCost & 0,375 \\
\hline & & InfAvailab & 0,125 \\
\hline & & OperCost & 0,125 \\
\hline
\end{tabular}

Analysis of results presented in Tab. 1, shows that experts believe that environmental issues are crucial for evaluating performance of AQMS. Location and technical issues could be considered also as quite important, while social and economic objective has marginal significance for evaluating AQMS.

Within the Environmental group of indicators, ConcLevels, TotEmiss and MonitToMonit indicators have significantly higher priorities compared to other three (DataCover - 0,076, TrendImp - 0,065, DevLimit -
0,059). Similar situation is within the Location/Technical group of indicators, where the LocatRepres indicator weight of 0,578 indicates dominance of this indicator over the other four. Second ranked indicator is AreaServ $(0,181)$, while the other three (NumParam, HistData, StatAccessib) have low significance for AQMS performance evaluation considering Location/Technical objective fulfilment. The priority order for the Social/Economic group is ExposedPopul $(0,375)$ and MaintenCost $(0,375)$ and InfAvailab $(0,125)$ and OperCost $(0,125)$.

By finishing second Step, decision making framework is defined. It can be used for the evaluation of AQMS performance on local and regional level in Vojvodina Province, as well as in other areas with similar scale and characteristics.

\section{Case study}

Municipality of Kikinda is located in the northeastern Serbia, near the Romanian border (Fig. 3). Total area is $783 \mathrm{~km}^{2}$ with 38065 inhabitants [31], and population density of 77 people $/ \mathrm{km}^{2}$ [32]. Kikinda is located in a Pannonia Plain and is surrounded by areas with intensive agricultural activity. The town and its surrounding area are also rich in oil and gas, as well as high quality clay which is the basis for the development of the exploitation of natural resources and construction industry.

The industrial zones in Kikinda are located in the northeast and in the southwest. Food industry (production of biscuits) is located in the north-eastern part while ceramic industry (production of tiles, bricks), metal (steel and aluminium) industry which produces parts for the car industry, and the chemical industry (methanol and acetic acid production) are in the southwestern part. Two AQMS are located near the industrial zone of Kikinda (Fig. 3). KISA is set in order to monitor the impact of the industrial zone, while KIMA serves as urban background. Characteristics of both stations are given in Tab. 2 . 
Table 2 KIMA and KISA stations characteristics [33]

\begin{tabular}{|c|c|c|}
\hline Abb. & KIMA & KISA \\
\hline Authority & SEPA & PSCEP \\
\hline Station type & Urban background & Industry \\
\hline Monitors & $\mathrm{SO}_{2}, \mathrm{NO}_{\mathrm{x}}, \mathrm{CO}$ & Benzene, $\mathrm{O}_{3}$ \\
\hline $\begin{array}{c}\text { Meteorological } \\
\text { parameters }\end{array}$ & $\begin{array}{c}\text { Direction and wind } \\
\text { speed, temperature, } \\
\text { relative humidity }\end{array}$ & $\begin{array}{c}\text { Direction and wind } \\
\text { speed, temperature, } \\
\text { relative humidity, } \\
\text { atmospheric pressure }\end{array}$ \\
\hline
\end{tabular}

Due to the proximity of the stations and necessity to reduce the costs of maintenance and operation, authorities expressed the interest to keep one station active and relocate the monitors from the other one.

To select the more suitable AQMS in Kikinda Municipality, authors used decision framework defined in previous section and asked experts to compare KISA and KIMA stations vs. all identified indicators.

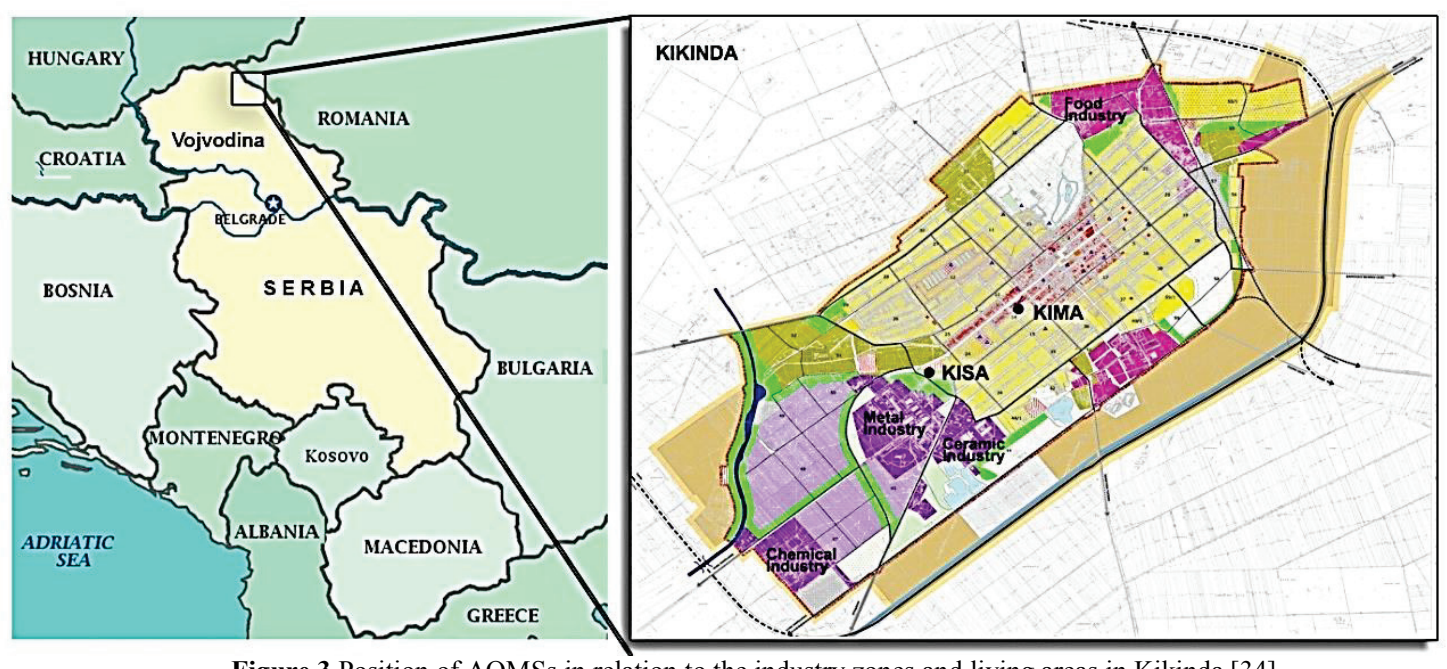

Figure 3 Position of AQMSs in relation to the industry zones and living areas in Kikinda [34]

In order to compare AQMSs detailed analysis of all criteria within each indicator were performed. In the context to the Environmental objectives, concentrations of nitrogen-dioxide, sulfur-dioxide and carbon-monoxide for the period of 2011/2014 (KIMA) as well as ozone and benzene concentration for the period of 2010/2014 (KISA) were analyzed. According to the results of analysis of available data it was identified that indicators ConcLevels, TotEmiss and MoniToMonit should be set as of equal importance since both AQMSs showed exceedance of limit values (for ozone in KISA) or upper assessment thresholds (for carbon-monoxide and nitrogen-dioxide in KIMA), both sites are influenced by the same sources and the same amount of pollutants (23), and there is no significant correlation with the stations that are classified as the same type (industrial and urban background AQMS). Indicator TrendImp showed higher importance of KISA, since a growing concentration trend for both parameters, ozone and benzene, was detected. In KIMA only one parameter (carbon-monoxide) showed increasing concentration trend, while the remaining two monitors (nitrogen-dioxide and sulfur-dioxide) showed declining concentration trend. The lowest percent of deviation of limit value (DevLimit) was recorded for ozone in KIMA which gives the elevated importance of this AQMS.

Analysis of the indicators within the Location/ Technical objectives showed increased compliance to the referred criteria of KIMA. LocRepres and StatAccessib were calculated according to the percent of fulfillment of defined criteria within each indicator. LocRepres showed lower value of compliance for KISA due to the position of AQMS and regarding to the criteria "free air flow", while indicators StatAccessib are set as equal for both AQMS.
NumParam and HisData were calculated according to the total number of measured parameters (eight for KIMA and 5 for KISA), as well as according to the number of operating years and available data (six years for KIMA and eight for KIMA).

Indicators of Social/ Economic objectives did not provide significant differentiation of the stations importance, due to the fact that there is the same number of potentially exposed population and there are no available data on maintenance and operational costs per individual analyzers.

Table 3 Performance of KISA and KIMA regarding each of the indicators

\begin{tabular}{|l|c|c|}
\hline \multicolumn{1}{|c|}{ Indicators } & KISA & KIMA \\
\hline Concentration levels & 0,50 & 0,50 \\
\hline Total emission & 0,50 & 0,50 \\
\hline Data coverage & 0,25 & 0,75 \\
\hline Trend impact & 0,67 & 0,33 \\
\hline Monitor to monitor correlation & 0,50 & 0,50 \\
\hline Deviation of limit values & 0,80 & 0,20 \\
\hline Location representativeness & 0,17 & 0,83 \\
\hline Area served & 0,50 & 0,50 \\
\hline $\begin{array}{l}\text { Number of parameters and measurement } \\
\text { methods }\end{array}$ & 0,25 & 0,75 \\
\hline Station accessibility & 0,50 & 0,50 \\
\hline Historical data & 0,75 & 0,25 \\
\hline Potentially exposed population & 0,50 & 0,50 \\
\hline Maintenance cost & 0,50 & 0,50 \\
\hline Information availability & 0,50 & 0,50 \\
\hline Operational cost & 0,50 & 0,50 \\
\hline
\end{tabular}

After the consensual linguistic pair-wise comparisons were completed and converted to numbers, performance of each of the stations regarding a certain indicator can be assessed by the calculated weight of the station given in 
Tab. 3. Since only two alternatives were assessed by AHP, consistency ratio was equal to 0 for all the AHP judgements.

Performance of KISA and KIMA was equal regarding 9 out of 15 indicators. KISA performed better than KIMA if indicators TrendImp, DevLimit and HistData are considered. KIMA performed better considering DataCover, LocatRepres and NumParam.

Having the local weights of KISA and KIMA (Tab. 3) and local weights of objectives and indicators (Tab. 1), it was now possible to perform AHP synthesis and obtain final weights of KISA and KIMA stations. Results of the synthesis (final weights) are:

- KISA station: 0,439 (rank 2),

- KIMA station: 0,561 (rank 1).

According to calculated weights, overall KIMA performance is better, and recommendation to responsible authorities is that KIMA station should stay within the network, while monitors from KISA should be relocated to KIMA.

\section{Conclusions}

Air quality monitoring network was established on the territory of Vojvodina Province, Serbia, during the 2000 s. As in many other countries, network was not systematically planned which resulted in total of 17 stations under three different authorities.

To evaluate performance of the stations at local and regional level in Vojvodina Province, authors have proposed and tested the applicability of the decision making framework based on the multi-criteria method AHP in group context. Three experts participated in identification of a comprehensive set of fifteen key performance indicators. Indicators were divided into three groups according to the following objectives: Environmental, Location/Technical and Social/Economic.

Decision problem is presented as the hierarchy, as required by AHP, and experts evaluated importance of objectives and indicators for the assessment of AQMS performance using the linguistic Saaty's scale. Consensual linguistic judgments were transformed to numbers, enabling obtaining local weights of given hierarchy elements. Calculated local weights showed that experts believe that for AQMS performance evaluation at local and regional level in Vojvodina, environmental objective is by far most important $(0,57$ - almost two thirds), while social and economic objective was assessed as with almost no significance (weight of 0,097).

Within the groups of indicators, it can also be seen that some of the indicators dominate over others (for example, LocatRepres within the Location/Technical objective, or ConcLevels within the Environmental objective). This fact leads to the conclusion that decision problem could be simplified by excluding some of the indicators.

Established decision framework (i.e. defined AHP model and calculated local weights of objectives and indicators) is then used to assess performance of two AQMSs in the Municipality of Kikinda, due to the necessity of reducing cost that authorities expressed. Experts evaluated KISA and KIMA regarding identified indicators using linguistic Saaty's scale and the consensus of experts on linguistic judgments is achieved through discussion. Evaluation is followed by converting linguistic into numerical judgments and calculating local weights of KISA and KIMA. AHP synthesis is then performed, resulting in global weights of alternative stations. Having higher weight and thus better overall performance, it can be recommended to authority to keep the KIMA station and to relocate ozone and benzene monitors to this location. This would significantly influence the cost reduction (primarily maintenance costs as well as the operating costs), while ensuring the continuity of the measurement and monitoring of pollutant concentration trends.

Besides relocation of the monitors, if the terrain type (arable area) as well as industry in the vicinity of the town is considered, recommendation to authorities is to install to KIMA also the particulate matter monitors.

Results of the application of proposed methodology proved usefulness of the approach, since defined framework can be used for further assessment of AQMS redundancy at local or regional level in Vojvodina. Also, the application of AHP was justified since it enabled transparency of the evaluation process and higher trust to the results since both experts and authorities could easily follow all steps: from selection of the indicators to defining how much the indicators are important for the evaluation (often used ranking methods give, for example, just the information on ordering).

Results of AHP application also brought to light importance of participation of different experts. Social and economic objective was considered here as with no importance comparing to environmental and Location/ Technical objectives, which could be explained by the educational and professional background of the participating experts. Thus, involvement of experts with different background (economics, engineering, policy making, etc.) and sensitivity analysis related to change of objectives' weights will be part of a further research to obtain decision that is more acceptable to broader spectra of professionals.

\section{References}

[1] Vujic, B.; Pavlovic, A.; Vujic, G.; Jevtic, D. Assessment of concentration levels of particulate matters (PM10, TSP and BS) in the area of Zrenjanin, Vojvodina, Serbia. // Revista de Chimie (Bucharest). 61, 10(2010), pp. 991-997.

[2] 40 CFR pt 58.10, Annual monitoring network plan and periodic network assessment Washington, DC: US National Archive and Records Administration, 2007.

[3] Raffuse, S. M.; Sullivan, D. C.; McCarthy, M. C.; Penfold, B. M.; Hafner, H. R. Ambient Air Monitoring Network Assessment Guidance: Analytical Techniques for Technical Assessments of Ambient Air Monitoring Networks. Research Triangle Park, NC: U. S. Environmental Protection Agency, 2007, URL: http://www.epa.gov/ ttnamti1/files/ambient/pm25/datamang/networkassessment-guidance.pdf (02.02.2015.).

[4] Penfold, B.; Hafner, H.; Raffuse, S. Analytical Techniques Used for Regional-Scale Network Assessments. // National Air Monitoring Conference. / Las Vegas, NV, November 69, 2006, URL: http://www.epa.gov/ttn/amtic/files/ 2006conference/hafnertraining.pdf.(17.04.2015). 
[5] Lu, W. Z.; He, H. D.; Li-Yun Dong, L. Y. Performance assessment of air quality monitoring networks using principal component analysis and cluster analysis. // Building and Environment. 46, 3(2011), pp. 577-583. DOI: 10.1016/j.buildenv.2010.09.004

[6] Pires, J. C. M.; Pereira, M. C.; Alvim-Ferraz, M. C. M.; Martins, F. G. Identification of redundant air quality measurements through use of principal component analysis. // Atmospheric environment. 43, 25(2009), pp. 3837-3842. DOI: 10.1016/j.atmosenv.2009.05.013

[7] Chen, C. H.; Liu, W. L.; Chen, C. H. Development of a multiple objective theory and system for sustainable air quality monitoring networks. // Science of the Total Environment. 354, 1(2006), pp. 1-19. DOl: 10.1016/j.scitotenv.2005.08.018

[8] Kao, J. J.; Hsieh, M. R. Utilizing multi- objective analysis to determine an air quality monitoring network in an industrial district. // Atmospheric Environment. 40, 6(2006), pp. 1092-1103. DOI: 10.1016/j.atmosenv.2005.11.003

[9] Mofarrah, A.; Husain, T. A holistic approach for optimal design of air quality monitoring network expansion in an urban area. // Atmospheric Environment. 44, 3(2010), pp. 432-440. DOI: 10.1016/j.atmosenv.2009.07.045

[10] Vlachokostas, Ch.; Achillas, Ch.; Moussiopoulos, N.; Banias, G. Multi- criteria methodological approach to manage urban air pollution. // Atmospheric Environment. 45, 25(2011), pp. 4160-4169. DOl: 10.1016/j.atmosenv.2011.05.020

[11] Kimbrough, S.; Vallero, D.; Shores, R.; Vette, A.; Black, K.; Martinez, V. Enhanced, multi-criteria based site selection to measure mobile source toxic air pollutants. // Transportation Research Part D. 16, 8(2011), pp. 586-590. DOI: 10.1016/j.trd.2011.07.003

[12] Pope, R.; Wu, J. A multi-objective assessment of an air quality monitoring network using environmental, economic, and social indicators and GIS-based models. // Journal of the Air and Waste Management Association. 64, 6(2014), pp. 721-737. DOI: $10.1080 / 10962247.2014 .888378$

[13] Saric, T.; Simunovic, K.; Pezer, D.; Simunovic, G. Inventory classification using multi - criteria $\mathrm{ABC}$ analysis, neural networks and cluster analysis. // Tehnicki vjesnikTechnical Gazette. 21, 5(2014), pp. 1109-1115.

[14] Agarski, B.; Kljajin, M.; Budak, I.; Tadic, B.; Vukelic, Dj.; Bosak, M.; Hodolic, J. Application of multi-criteria assessment in evaluation of motor vehicles' environmental performances. // Tehnicki vjesnik-Technical Gazette. 19, 2(2012), pp. 221-226

[15] Tseng C. C.; Chang N. Assessing relocation strategies of urban air quality monitoring stations by GA-based compromise programming. // Environment International. 26, 7-8(2001), pp. 523-541.

[16] Nikolic, Dj.; Milosevic, N.; Mihajlovic, I., Zivkovic, Z.; Tasic, V.; Kovacevic, R.; Petrovic, N. Multi-criteria Analysis of Air Pollution with $\mathrm{SO}_{2}$ and PM10 in Urban Area Around the Copper Smelter in Bor, Serbia. // Water Air Soil Pollut. 206, 1-4(2010), pp. 369-383.

[17] Gorai, A. K.; Kanchan; Upadhyay, A.; Goyal, P. Design of fuzzy synthetic evaluation model for air quality assessment. // Environment Systems and Decisions. 34, 3(2014), pp. 456-469.

[18] Saaty T. L. The Analytic Hierarchy Process, McGraw-Hill International Book, New York, NY, USA, 1980.

[19] Khan, F. I.; Sadiq, R. Risk-based prioritization of air pollution monitoring using fuzzy synthetic evaluation technique. // Environmental Monitoring and Assessment. 105, 1-3(2005), pp. 261-283. DOI: 10.1007/s10661-005-38521

[20] Shao, H.; Yang, L.; Han, Y. Evaluation Model Based on Analytic Hierarchy Process and Applications in Indoor Air Quality Monitoring System. // Proceedings of the $6^{\text {th }}$
Intelligent Networks and Intelligent Systems Conference, 13 November 2013, Shenyang, China, pp. 9-12. DOl: 10.1109/icinis.2013.9

[21] Upadhyay, A.; Kanchan; Goyal, P.; Yerramilli, A.; Gorai, A. K. Development of a Fuzzy Pattern Recognition Model for Air Quality Assessment of Howrah City. // Aerosol and Air Quality Research. 14, 6(2014), pp. 1639-1652.

[22] Regulation on conditions for monitoring and requirements of air quality ("Official Gazette RS" No. 11/2010).

[23] Agency for Environmental Protection, Republic of Serbia, Annual report on Air Quality in Republic of Serbia for 2013, ISSN 2334-8763, URL: http://www.sepa.gov.rs/ download/VAZDUH2013.pdf(13.04.2015)

[24] LADCO 2010, DRAFT REPORT, Regional Network Assessment, States of Illinois, Indiana, Michigan, Minnesota, Ohio, and Wisconsin, URL: http://www.ladco.org/reports/general/Regional_Network_A ssessment/index.html (19.04.2015)

[25] Scheffe, R.; Husar, R.; Falke, S. Compliance Monitoring (Deviation from NAAQS), Center for Air Pollution Impact and Trend Analysis, CAPITA Washington University, St. Louis, December 2000, URL: http://capita.wustl.edu/capita/ capitaReports/PPT_CAPITA/AQMan_Monitoring/NetAsse ssCompl0012.ppt (30.04.2015)

[26] Directive 97/101/EC: Council Decision of 27 January 1997 establishing a reciprocal exchange of information and data from networks and individual stations measuring ambient air pollution within the Member States.

[27] Directive 2008/50/EC of the European Parliament and of the Council of 21. May 2008 on ambient air quality and cleaner air for Europe.

[28] Plate, M. Evaluating Sitting of Air Monitoring Stations. // EPA Region 9, 2012, URL: http://www.epa.gov/ttn/amtic/ files/2012conference/3C03Plate.pdf (13.04.2015)

[29] Larssen,S.; Sluyter, R.; Helmis, C. Criteria for EUROAIRNET - The EEA Air Quality Monitoring and Information Network (1999), Technical report No 12,URL: http://www.eea.europa.eu/publications/TEC12 (19.04.2015)

[30] Scheffe, R. D.; Solomon, P. A.; Husar, R.; Hanley, T.; Schmidt, M.; Koerber, M.; Gilroy, M.; Hemby, J.; Watkins, N.; Papp, M.; Rice, J.; Tikvart, J.; Valentinetti, R. The National Ambient Air Monitoring Strategy: Rethinking the role of national networks. // Journal of the Air \& Waste Management Association. 59, 5(2009), pp. 579-590. DOI: 10.3155/1047-3289.59.5.579

[31] Census of Population 2011, Households and Dwellings in the Republic of Serbia, Statistically office of the Republic of Serbia, URL: http://webrzs.stat.gov.rs/WebSite/ (15.06.2015)

[32] Municipalities and Regions in Republic of Serbia 2012, Statistical office of the Republic of Serbia, URL: http://webrzs.stat.gov.rs/WebSite/ (19.06.2014)

[33] Regulation on the Implementation Program of air quality control in the national network ("Official Gazette of RS", no. $58 / 11)$.

[34] General urban plan 2006 of Kikinda ("Official Gazette Kikinda" No. 4/06, 2/08, 19/08, 26/08, 7/09, 18/09, 4/2010), URL: http://www.zavurbvo.co.rs/urbanisticki.php (30.04.2015) 


\section{Authors' addresses}

Bogdana Vujic, PhD, assistant professor

University of Novi Sad,

Technical faculty "Mihajlo Pupin",

Djure Djakovica bb,

23000 Zrenjanin, Serbia

E-mail: bogdana.vujic@tfzr.rs

Zorica Srdjevic, PhD, associate professor

University of Novi Sad

Faculty of Agriculture

Trg Dositeja Obradovica 8

21000 Novi Sad, Serbia

E-mail: srdjevicz@polj.uns.ac.rs

Boris Agarski, PhD, assistant professor

University of Novi Sad,

Faculty of Technical Sciences,

Trg Dositeja Obradovica 6,

21000 Novi Sad, Serbia

E-mail: agarski@uns.ac.rs

Katica Simunovic, PhD, full professor

J. J. Strossmayer University of Osijek,

Mechanical Engineering Faculty in Slavonski Brod,

Trg Ivane Brlic-Mazuranic 2,

35000 Slavonski Brod, Croatia

E-mail: Katica.Simunovic@sfsb.hr 